\title{
Communication Technology Use for Work at Home during Off-job Time and Work- Family Conflict: The Roles of Family Support and Psychological Detachment
}

\author{
Zhenyuan Wang ${ }^{\mathrm{a}, \mathrm{b}, \mathrm{c}}, \mathrm{Xi}$ Chen ${ }^{\mathrm{d} *}$, and Yongjia Duan ${ }^{\mathrm{e}}$ \\ a Faculty of Economics and Management, East China Normal University(China), \\ ${ }^{b}$ Antai College of Economics and Management, Shanghai Jiaotong University(China), \\ ${ }^{c}$ Resesarch Institute of International Business and Management, Peking University(China), \\ ${ }^{d}$ College of Humanity and Communication, Shanghai Normal University(China), \\ e Shanghai Shangfang Tech. Ltd. Co. (China).
}

\begin{abstract}
Título: Uso de la tecnología de comunicación para el trabajo en casa durante el tiempo fuera del trabajo y el conflicto trabajo-familia: los roles del apoyo familiar y el desapego psicológico.

Resumen: Este estudio analiza la influencia del uso de las tecnologías de la comunicación para el trabajo en casa durante el tiempo fuera del trabajo en el conflicto trabajo-familia. Nuestro análisis se basa en la teoría de los límites entre trabajo y familia. Por otra parte, este estudio destaca los roles de desapego psicológico y apoyo familiar. Sobre la base de 423 participantes, utilizamos el análisis de regresión para probar nuestras hipótesis. Los resultados muestran que el uso de la tecnología de comunicación para trabajar en casa durante el tiempo fuera del trabajo se relaciona positivamente con el conflicto entre el trabajo y la familia, incluyendo los conflictos basados en el tiempo y la tensión. El apoyo de la familia modera el efecto del uso de las tecnologías de la comunicación para el trabajo en casa durante el tiempo fuera del trabajo en el conflicto laboral-familiar del empleado. Además, e desapego psicológico media el efecto moderador del apoyo familiar sobre la relación entre el uso de las tecnologías de la comunicación para el trabajo en casa durante el tiempo fuera del trabajo y el conflicto entre el trabajo y la familia.

Palabras clave: uso de tecnología de comunicación para el trabajo en casa; conflicto trabajo-familia; apoyo familiar; desapego psicológico; límites trabajo-familia.
\end{abstract}

\section{Introduction}

Employees currently suffer from increased work burden, and that results in extended working hours for many of them. Research has been increasing on the effects of working overtime on employee life. For example, Greenhaus, Bedeian, and Mossholder (1987) explained that working for long hours could significantly influence how people manage their work and family life. Several scholars, such as Byron (2005), drew the same conclusion from their research in which individuals who worked extended hours had reported additional work-family conflicts.

The rapid development of technology has enabled the extensive use of powerful electronic devices, such as smart phones, laptops, and tablet PCs, to facilitate efficient communication across time and space (Adkins \& Premeaux, 2014). On the one hand, communication technology enables employees to work from home during work time, that is, telework(ing) (Chesley, 2005; Edley, 2001; Ellison, 2004); telework can lower levels of various dimensions of work-family

The research was supported by grants from the National Natural Science Foundation of China (71102029; 71372081; 71672060).

* Correspondence address [Dirección para correspondencia]:

Xi Chen. Humanities and Communication, Shanghai Normal University (China). E-mail: cx2006@shnu.edu.cn
Abstract: This study analyzes the influence of communication technology use for work at home during off-job time on work-family conflict. Our analysis is based on work-family border theory. Moreover, this study highlights the roles of psychological detachment and family support. Based on 423 samples, we use regression analysis to test our hypotheses. Results show that communication technology use for work at home during off-job time is related to employee work-family conflict positively, including timebased and strain-based conflicts. Family support moderates the effect of communication technology use for work at home during off-job time on employee work-family conflict. Furthermore, psychological detachment mediates the moderating effect of family support on the relationship between communication technology use for work at home during off-job time and employee work-family conflict.

Key words: communication technology use for work at home; workfamily conflict; family support; psychological detachment; work-family border. conflict (Madsen, 2003). On the other hand, employees can continue their work at home during off-job time with the aid of communication technology, thereby enabling them to come back home on time (König, Kammerlander, \& Enders, 2013). However, only a few studies have analyzed the effect of using technology at home during off-job time on work-family conflict. Thus, in this study, we would try to study the effect of technology use for work at home during off-job time on employee work-family conflict, as well as investigate the mediating and moderating variables of the relationship.

Using communication technology for work at home during off-job time consciously or unconsciously connects people with work; thus, determining the manner by which such practice influences employee family life is imperative. However, a few empirical studies explain this effect. Golden (2013) proved the direct effect of technology use for work on work-family conflict; however, the author did not investigate the mechanism that leads to the occurrence of such effect. The current study reveals the roles of family support and psychological detachment between afore mentioned two variables. 


\section{Communication technology use for work at home during off-job time and work-family conflict}

Work-family border theory was proposed by Clark in 2000. This theory explains how people manage and coordinate their work and family life, as well as the boundaries between them. This theory elucidates that people are bordercrossers because they cross between the working and nonworking domains daily. Work-family border theory separates the working and nonworking domains and clarifies the boundaries. Clark (2000) explained that border-crossers have to frequently switch between working and nonworking roles (i.e., family and leisure), such as being employees and parents.

Work-family border theory also elaborates that the permeability and flexibility of the border between work and family life would disturb the work-family balance and lead to conflicts between work and personal life (Clark, 2000). Greenhaus and Beutell (1985) defined work-family conflict as the conflict between roles that resulted from the pressures of work and life, as well as in the difficulty in coordinating such roles. The different requirements of these two roles mean that satisfying one will result in difficulty meeting the demand of the other (Greenhaus \& Beutell, 1985). In particular, investment on the role of work will lead to difficulty in focusing on the role of family life. Similarly, investment on the role of family will result in difficulty focusing on the role of work. The three types of work-family conflicts are timebased, strain-based, and behavior-based conflicts. If employees consume time to meet the demands of a domain, which should be originally used for the other domain, then timebased conflict is generated. If a domain generates dissatisfaction, nervousness, anxiety, and exhaustion, then an individual will have difficulty in meeting the demands of the other. This situation is an example of strain-based conflict. If the behaviors required by the roles of one domain contradict the behaviors of the other roles of another domain, and individuals are unable to adjust, then behavior-based conflict emerges. However, empirically measuring behavior-based conflict is difficult and only a few studies have analyzed such issue (Kelloway, Gottlieb, \& Barham, 1999). Thus, we focus on the manner by which communication technology use for work at home during off-job time influences employee timebased and strain-based conflicts.

Work-family border theory emphasizes that the border refers to the limits of people and objects, or borders between domains that enable people to clearly define themselves. The three different types of borders are physical, temporal, and psychological borders, which separately define proper behavior, thinking, and emotion in certain domains (Clark, 2000). Permeability of borders refers to the extent by which individuals are allowed to be physically, behaviorally, or psychologically involved in another domain (Clark, 2000; Pleck, 1977; Richter, 1992). The rapid development of modern technology and infrastructure construction of the Internet have enabled people to adjust to answering work-related calls and dealing with work requests at home and during offjob time. If employees use technology for work at home during off-job time, then the physical, temporal, and psychological borders of the work domain are expected to expand and permeate to the non-work domain (i.e., family domain) (Chesley, Moen, \& Shore, 2003; Shamir, 1992). Employees no longer work in a particular office location and their time for work is no longer fixed. Work-family border theory emphasizes that the higher the level of the border's permeability, the more possible it will be for the two domains to interfere with each other; therefore, work-family conflict emerges easily (Powell \& Greenhaus, 2010).

Time-based and strain-based conflicts may easily come up because of the limited time and energy of employees. On the one hand, frequently using technology for work at home during off-job time will consume or occupy the time that one should devote to family life. Consequently, one realizes the intensified time-based work-family conflict (Allen \& Finkelstein, 2014). On the other hand, such situation will cause pressure and tension from work to affect the family. Personal resources (e.g., energy and psychological ability) decrease because of pressure and tension; thus, conflict between roles breaks out (Pleck, Staines, \& Lang, 1980; Teo, Newton, \& Soewanto, 2013). Based on the afore mentioned arguments, we propose the following hypotheses:

Hypothesis 1: Technology use for work at home during off-job time is positively associated with employee (a) timebased work-family conflict; (b) strain-based work-family conflict.

\section{Moderating effect of family support}

Work-family border theory explains that border-keepers are people who influence the border defining the process. These people, who participate in activities in anindividual's working or non-working domains, include colleagues, leaders in the working domain, and couples, parents, children in the family domain, as well as companies or partners in entertainment or religious activities (Clark, 2000; Greenhaus \& Beutell, 1985). For example, border-keepers, such as couples and children, maintain the border by providing family support. Family members provide individuals emotional support for their work and are willing to extend assistance in everyday life (Treiber \& Davis, 2012).

Work-family border theory also emphasizes that borderkeepers play an important role when border-crossers cross the border. Border-keepers provide resources and energy for border-crossers to reduce or eliminate conflicts between work and family life. Moreover, effective communication between border-keepers and border-crossers can assist the latter to balance work and family life. Family support can significantly enhance the flexibility of the border and further reduce work-family conflict, whereas individuals who lack family support can easily encounter work-family conflict (Behson, 2002; Carlson, 1999; Crzywacz \& Marks, 2000; Parasurman \& Simmers, 2001; William \& Alliger, 1994). 
Providing additional support will enable family members to acquire an improved understanding of the work requirement of employees and show further respect for their willingness to work (Clark, 2000; Hall \& Richter, 1988). For example, family members can undertake additional housework, which is supposed to be done by border-crossers, to increase the family border's flexibility. Therefore, when employees use technology for work at home during off-job time and with additional family support, they would not be asked by their family for further attention and devotion, thereby reducing time-based conflict. Furthermore, high family support enables individuals to share their joy and sorrow with family members, thereby facilitating the employees' release of negative emotions (e.g., dissatisfaction, intense, anxiety, and exhaustion) resulting from work (Bagger \& Li, 2014). Moreover, high family support reduces strain-based work-family conflict. Thus, we propose following hypotheses:

Hypothesis 2: Family support will decrease the effects of technology use for work at home during off-job time on employee (a) time-based work-family conflict; (b) strainbased work-family conflict.

Psychological detachment defines the extent that individuals psychologically detach themselves from working states during off-job time (Etzion, Eden, \& Lapidot, 1998). Individuals have to physically release themselves from work and recover from intense work pressure (Park, Fritz, \& Jex, 2011). Sonnentag and Fritz (2007) indicated that psychological detachment refers to the state when employees are not occupied with work responsibilities. For example, employees will not receive work-related calls or engage in work-related activities. They further described psychological detachment as a recovering experience that aids employees to restore the psychological resources consumed by their work. Moreover, Sonnentag, Kuttler and Fritz (2010) concluded that the border between work and family is associated with the level of employees' psychological detachment; employees will have low psychological detachment if they worked at home during off-job time. Park et al. (2011) proved that the negative correlation between technology use for work at home during off-job time and psychological detachment. Using technology for work at home during off-job time means continuing work in the nonworking domain and time. Hence, employees' working behaviors and emotions will permeate their family life, thereby leading to low psychological detachment from work.

The flexibility of border refers to "the flexibility of an element entering into another domain, or the flexible level of time and space borders/boundaries" (Clark, 2000; Hall \& Richter, 1988). People can change behavior and thinking patterns, as well as emotions, according to the border flexibility based on certain situation, time, and space. Richardson and Thompson (2012) determined that family support considerably assists individuals to switch roles between fields (i.e., increase flexibility of border), thereby enabling them to generate the proper behaviors and emotions. Therefore, compared with low family support, high family support means that family members can express their concerns for employees, be sensitive to employees' requirements, adjust the family climate, or provide assistance. Such forms of support relieve the work pressure from employees, thereby decreasing the negative effects of technology use for work at home during off-job time on employees' psychological detachment. Therefore, we propose the following hypothesis:

Hypothesis 3: Family support will decrease the negative effects of technology use for work at home during off-job time on psychological detachment.

\section{Mediating effect of psychological detachment}

A considerably high psychological detachment from work will assist employees mitigate the feeling of exhaustion the next morning (Sonnentag \& Bayer, 2005; Sonnentag \& Binnewies, 2008). Psychological detachment was also proven to be positively and negatively associated with life satisfaction and emotional exhaustion, respectively (Park et al., 2011; Sonnentag et al., 2010). Therefore, a high level of psychological detachment will decrease the negative effects of work pressure(strain-based), guide employees to immediately focus on family life (time-based), and increase individuals' feelings of happiness (Fritz, Yankelevich, Zarubin, \& Barger, 2010). Thus, we propose the following hypotheses:

Hypothesis 4: The moderating effect of family support will affect (a) time-based work-family conflict and (b) strainbased work-family conflict through the mediating effect of psychological detachment.

Figure 1 provides the research model to present the preceding hypotheses.

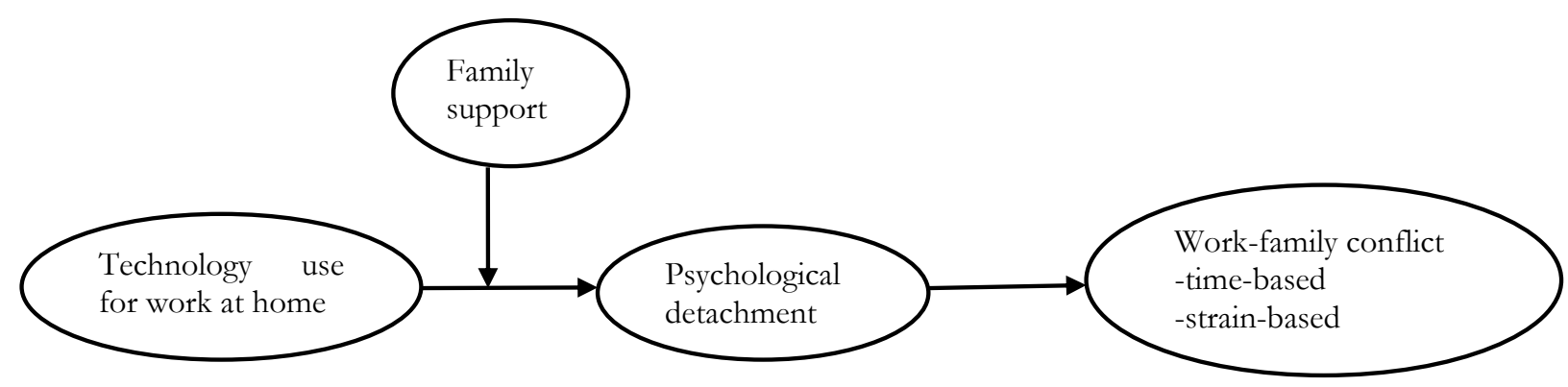

Figure 1. Research Model. 


\section{Method}

\section{Sample and Procedure}

The participants in this study were employees of several companies in Shanghai. We collected data at two time waves within two months to reduce the effects of common method variance. To investigate the independent variables (technology use for work at home during off-job time) and moderating variable (family support), we distributed questionnaires to 600 employees at Time One and received usable responses from 561 participants $(93.5 \%$ response rate). At Time Two (one months later), we investigated the mediating variable (psychological detachment) and dependent variable (work-family conflict). We received usable responses from 423 employees for a usable response rate of $75.4 \%$. Among these respondents, $40.4 \%$ were males and $59.6 \%$ were females, $18 \%$ were 25 year-old or below, $62 \%$ were 26 to 35 year-old, $16 \%$ were 36 to 45 year-old, and $3.8 \%$ were 46 year-old or above. Most respondents hold bachelor's degrees (67.4\%), 20.3\% reached junior college, 2.8\% had high school education, and the rest ones $(9.5 \%)$ hold master's degrees or above. Most respondents (64.7\%) were married, and 35.3\% were single; $45.2 \%$ of the respondents don't have any child, $53 \%$ with one child, and $1.9 \%$ with two children. In our sample, $42.3 \%$ were regular staff members, $35.9 \%$ were firstline supervisors, $18.7 \%$ were mid-level managers, and $3.1 \%$ were senior managers. The participants worked for different ownership-type companies: $26.7 \%$ were from state-owned enterprises, $29.1 \%$ were from private enterprises, $21.2 \%$ were from foreign enterprises, $18.7 \%$ were from joint venture enterprises, and $4.3 \%$ were from others.

\section{Measures}

The questionnaire included four subscales, namely, technology use for work at home during off-job time, family support, psychological detachment, and work-family conflict.

Technology use for work at home during off-job time. We adopted the scale developed by Park et al. (2011) to measure technology use for work at home during off-job time. Five items were used, including, "I would use computer for my work at home during off-job time" and "I would use mobile devices (such as smart phones and tablets) for my work at home during off-job time."'The participants responded in a 5-point scale ranging from $1=$ strongly disagree to $5=$ strongly agree. Cronbach's alpha for this scale was .89 .

Family support. This variable was measured using the five-item scale developed by Caren, Elizabeth, Dena, and Joseph (2002), including "When something goes wrong at work, I can talk it over with my family," "My family cares about how I feel about my job," and "My family helps me feel better when I've had a hard day at work." Cronbach's alpha for this scale was .90 . The respondents were asked to indicate the extent to which they agreed $(1=$ strongly disagree to $5=$ strongly agree) with each item describing how their family supported them.

Psychological detachment. The scales of Sonnentag and Fritz (2007) and Park et al. (2011) were adapted to measure psychological detachment. Four items were used, including "During my non-work time, I distance myself from work" and "During my off-job time, I don't think about work at all." Cronbach's alpha for this scale was .85.The respondents indicated the extent how they detached from work during off-job time using a Likert 5-point scale $(1=$ strongly disagree; $5=$ strongly agree $)$.

Work-family conflict. The scale developed by Kelloway et al. (1999) was adapted to measure work-family conflict, and included the two dimensions of time-and strain-based conflicts. Time-based conflict had five items, including "I have to change plans with family members because of the demands of my job," "To meet the demands of my job, I have to limit the number of things I do with family members," and "Job demands keep me from spending the amount of time I would like with my family." Strain-based conflict had six items, including "After work, I have little energy left for the things I need to do at home," "After work, I just need to be left alone for a while," and "The demands of my job make it hard for me to enjoy the time I spend with my family." The scale of time-based conflict had a Cronbach's alpha of .91, whereas that of the strain-based conflict was .88. Those two scales using time were answered using a Likert 5-point scale (1=strongly disagree; 5=strongly agree).

Control variables. The control variables included gender, age, educational background, marriage, position, corporate ownership, and social desirability. Gender was coded " 1 " for males and " 0 " for females. The respondents provided their ages in the questionnaire. Education level was measured by1, 2, 3, and 4 points, which referred to "high school and below," "junior college," "bachelor's," and "master's and above," respectively. Marriage was code " 1 " for single and " 2 " for marriage. The respondents reported their number of children. Position was measured based on 1 to 4 points for "regular staff member," "first-line supervisor," "mid-level manager," and "senior manager," respectively.

\section{Results}

\section{Confirmatory Factor Analysis}

We conducted confirmatory factor analysis (CFA) to ensure the validity of all constructs. We adopted the procedures according to Hui, Lee, and Rousseau (2004) for constructs with over three items. Initially, based on the result of factor analysis, the highest and lowest loaded items of a construct were combined into one item. Thereafter, we combined the second highest and second lowest loaded items of a construct into one item. This process was continued until 
each construct only had three items. Table 1 shows the CFA results. The fitness values of the hypothesized five-factor model $(T L I=.96 ; C F I=.97)$ are both greater than the generally recognized standard value (.90). For RMSEA, the value of the hypothesized five-factor model is .06, which was lower than the standard value (.08), thereby indicating a good fit for the hypothesized model. The model has good convergent validity because the factor loadings of measuring items and latent variables are all significantly above 0.5 .

Furthermore, we compared the hypothesized model with four alternative models. The hypothesized five-factor model fits better than the other four alternative models. The value of the hypothesized five-factor model for RMSEA is the lowest among all the models, thereby indicating a better fit for the data (see Table1). These results indicate that the five factors can be distinguished from one another; thus, this study has good discriminant validity.

Table 1. Results of Confirmatory Factor Analysis.

\begin{tabular}{lcccccc}
\hline & $\chi^{2}$ & Df & $\Delta \chi^{2}$ & CFI & TLI & RMSEA \\
\hline $\begin{array}{l}\text { Five-factor model } \\
\text { (hypothesized) }\end{array}$ & 220.08 & 80 & - & .97 & .96 & .06 \\
Four-factor model & 1028.51 & 84 & $808.43^{* *}$ & .78 & .72 & .16 \\
Three-factor model & 1210.90 & 87 & $990.82^{* *}$ & .73 & .68 & .18 \\
Two-factor model & 1714.55 & 89 & $1494.47^{* *}$ & .61 & .54 & .21 \\
Single factor model & 2433.32 & 90 & $2213.24 * *$ & .44 & .35 & .25 \\
\hline
\end{tabular}

${ }^{*} p<.05,{ }^{*} p<.01,{ }^{* *} p<.001$

Note: The four-factor model: the family support and psychological separation merged into one factor; three-factor model: the family support and psychological separation merged into one factor, and the variable time-based work - family conflict and strain-based work - family conflict merged into another factor; two-factor model: the family support, psychological separation, time-based work - family conflict and pressure-based work - family conflict merged into one factor; single-factor model: all variables merged into one factor.

Common method bias may be a concern for this study because the data were collected using a single method and from a single source. Therefore, we applied the procedures suggested by Podsakoff et al. (2003) to minimize bias and adopted statistical remedies to assure the validity of the current study. First, we used neutral words in the questionnaire statement to prevent revealing the objective, intention, and variables of this study, thereby reducing framing respondents and achieving good psychological separation. Second, the anonymity of the respondents and confidentiality of the responses were guaranteed to encourage them to answer the questions according to reality. Third, we collected variables at two time waves, which were independent and moderating variables at Time 1, and mediating and dependent variables at Time 2. Two months passed before we conducted the Time 2 activity. Furthermore, we asked the respondents to answer the questions concerning social desirability. Thereafter, we used the responses in the data analysis as a control variable to ensure that the answers will not cause false results. Finally, we applied the Harman one-factor test to statistically test potential common method bias (Podsakoff et al., 2003). Principal factor analysis with varimax rotation was used to determine whether a single factor explained a majority of variance. The results showed that the factor with the largest eigen value merely accounted for $17.39 \%$ of the total variance. The CFA results (see Table 1) showed a bad fit for the single-factor model, thereby demonstrating that one factor caused by a common method/source was not possible. Therefore, common method bias was an unlikely threat to the results of this study.

\section{Tests of Hypotheses}

Table 2 shows the means, standard deviations, and zero Pearson correlations of all variables of this study. Technology use for work at home during off-job time is significantly positively correlated with time-based work-family conflict $(r$ $=.24, p<.01)$ and strain-based work-family conflict $(r=.12$, $p<.05)$. The factor is significantly negatively correlated with psychological detachment $(r=-.20, p<.01)$. Moreover, psychological detachment is significantly negatively correlated with time-based work-family conflict $(r=-.36, p<.01)$ and strain-based conflict $(r=-.35, p<.01)$. These correlation results provided preliminary evidence supporting the theoretical hypotheses.

Table 2. Means, Standard Deviations and Pearson Correlation Coefficients ( $N=423)$.

\begin{tabular}{|c|c|c|c|c|c|c|c|c|c|c|c|c|c|}
\hline Variables & Mean & $S D$ & 1 & 2 & 3 & 4 & 5 & 6 & 7 & 8 & 9 & 10 & 11 \\
\hline \multicolumn{14}{|l|}{ 1. Gender } \\
\hline 2. Age & 31.30 & 6.72 & $-.14^{* *}$ & & & & & & & & & & \\
\hline 3. Education level & 2.83 & .62 & .02 & $-.18^{* *}$ & & & & & & & & & \\
\hline 4. Marriage & 1.65 & .48 & $-.15^{* *}$ & $.52 * *$ & -.08 & & & & & & & & \\
\hline 5. No. of children & .57 & .53 & $.16^{* * *}$ & $.54 * * *$ & $-.11 *$ & $.77 * * *$ & & & & & & & \\
\hline 6. Position & 1.83 & .89 & $.16^{* * *}$ & $.32 * * *$ & $.13^{* *}$ & $.31 * * *$ & $.34 * * *$ & & & & & & \\
\hline 7. Technology use for work at home & 3.34 & .89 & $-.10^{*}$ & -.09 & $.22^{* * *}$ & .00 & $.15^{* *}$ & $.28^{* * *}$ & (89) & & & & \\
\hline 8. Family support & 3.80 & .69 & .02 & -.02 & $.18^{* * *}$ & .06 & .03 & $.10^{*}$ & $.15^{* *}$ & $(90)$ & & & \\
\hline 9. Psychological detachment & 3.37 & .75 & -.07 & -.01 & $-.11 *$ & .05 & .04 & -.03 & $-.20 * *$ & $.16^{* *}$ & $(85)$ & & \\
\hline 10. Time-base conflict & 2.90 & .82 & $.15^{* *}$ & -.07 & .03 & -.04 & -.03 & .05 & $.24^{* *}$ & .01 & $-.36 * *$ & $(91)$ & \\
\hline 11. Strain-based conflict & 3.00 & .77 & .02 & $-.14 * *$ & .02 & $-.13 * *$ & $-.15^{* *}$ & -.04 & $.12 *$ & $-.16^{* *}$ & $-.35 * *$ & $.71 * *$ & $(0.88)$ \\
\hline
\end{tabular}

Cronbach's alphas for the scales are in parentheses and presented along the diagonal. SD = Standard deviation. $* p<.05,{ }^{* *} p<.01, * * * p<.001$

Our study proposed a mediated moderating model; hence, we followed the procedures suggested by Muller,
Judd, and Yzerbyt (2005) to test our hypotheses. The procedures are as follows. First, we regressed the dependent vari- 
able $(\mathrm{Y})$ by the independent variable $(\mathrm{X})$, moderating variable $(\mathrm{Mo})$, and moderating variable $\times$ independent variable (MoX). The coefficient of MoX should be significant (see Models 3 and 8 in Table 3). Second, we regressed the mediating variable $(\mathrm{Me})$ by $\mathrm{X}, \mathrm{Mo}$, and MoX. The coefficient of MoX should be significant (see Model 13 in Table 3). Third, we regressed $\mathrm{Y}$ by X, Mo, MoX, Me, and MoMe. The coef- ficient of Me should be significant, whereas the coefficient of MoX is no longer significant or the significance level should decrease (see Models 5 and 10 in Table 3). Hierarchical regression analysis was performed to test our hypotheses, and the control variables were included in the model to increase internal validity. Table 3 shows the results.

Table 3. Results of Regression Analysis ( $N=423)$.

\begin{tabular}{|c|c|c|c|c|c|c|c|c|c|c|c|c|c|}
\hline \multirow{3}{*}{ Variables } & \multicolumn{10}{|c|}{ Dependent variables } & \multicolumn{3}{|c|}{ Mediator } \\
\hline & \multicolumn{5}{|c|}{ Time-based conflict } & \multicolumn{5}{|c|}{ Strain-based conflict } & \multicolumn{3}{|c|}{ Psychological detachment } \\
\hline & Model 1 & 1 Model 2 & Model 3 & Model 4 & Model 5 I & Model 6 & Model 7 & Model 8 & Model 91 & Model 10 & Model 11 & Model 12 & Model 13 \\
\hline Gender & $.15^{*}$ & $.13^{*}$ & $.13^{*}$ & $.11^{*}$ & $.11^{*}$ & .04 & .04 & .03 & .02 & .02 & -.07 & -.05 & -.05 \\
\hline Age & -.08 & -.04 & -.04 & -.07 & -.07 & -.10 & -.08 & -.8 & -.11 & -.11 & -.07 & -.09 & -.10 \\
\hline Education level & .01 & -.02 & -.02 & -.06 & -.06 & -.01 & -.00 & -.00 & -.04 & -.04 & $-.11 *$ & -.11 & -.11 \\
\hline Marriage & -.07 & -.06 & -.06 & -.04 & -.04 & -.02 & .01 & .02 & .04 & .04 & .10 & .06 & .05 \\
\hline No. of Children & .02 & .02 & .01 & .02 & .02 & -.10 & -.11 & -.12 & -.11 & -.11 & .00 & .02 & .03 \\
\hline Position & .07 & -.00 & .00 & .01 & .01 & .02 & -.01 & -.00 & .01 & .01 & -.02 & .04 & .03 \\
\hline Technology use for work at home(A) & & $.23^{* * *}$ & $.23 * * *$ & $.16^{*}$ & $.15^{*}$ & & $.14^{* *}$ & $.14^{*}$ & .07 & .07 & & $-.22 * * *$ & $-.22 * * *$ \\
\hline Family support(B) & & -.02 & -.02 & .05 & .05 & & $-.18^{* * *}$ & $-.18 * * *$ & $-.12 * *$ & $-.12 *$ & & $.20 * * *$ & $.21 * * *$ \\
\hline$A * B$ & & & $-.11 *$ & -.07 & -.06 & & & $-.13 * *$ & $-.09 *$ & $-.09 *$ & & & $.13^{* *}$ \\
\hline Psychological detachment (C) & & & & $-.32 * * *$ & $-.32 * * *$ & & & & $-.31 * * *$ & $-.31 * * *$ & & & \\
\hline $\mathrm{B}^{*} \mathrm{C}$ & & & & & .02 & & & & & .00 & & & \\
\hline $\mathrm{R}^{2}$ & .03 & .08 & .09 & .18 & .18 & .03 & .07 & .09 & .17 & .17 & .02 & .09 & .11 \\
\hline Adjusted $\mathrm{R}^{2}$ & .02 & .06 & .07 & .16 & .16 & .02 & .05 & .07 & .15 & .15 & .01 & .08 & .09 \\
\hline$\Delta \mathrm{R}^{2}$ & $.03^{*}$ & $.04 * * *$ & $.01 *$ & $.09 * * *$ & .00 & $.03 *$ & $.04 * * *$ & $.01 * *$ & $.08 * * *$ & .00 & $.02 *$ & $.07 * * *$ & $.02 * *$ \\
\hline $\mathrm{F}$ & $2.37 *$ & $4.30 * * * 4$ & $4.44 * * *$ & $9.08^{* * *}$ & $8.26^{* * *}$ & $2.12 *$ & $3.97 * * *$ & * $4.43 * * *$ & $8.52 * * *$ & $7.72 * * *$ & 1.57 & $5.25^{* * *}$ & 5.60 \\
\hline
\end{tabular}

Model 2 shows that technology use for work at home during off-job time has a positive effect on time-based work-family conflict $(\beta=.23, p<.001)$, thereby supporting Hypothesis 1a. In Model 3, we further added the interactive term "technology use for work at home during off-job time $\times$ family support." The coefficient is significant $(\beta=-.11, p$ $<.05)$, thereby indicating that family support has a negative moderating effect on the main effect of technology use for work at home during off-job time on time-based workfamily conflict. This result supports Hypothesis 2a. Model 13 shows that the interactive term "technology use for work at home during off-job time $\times$ family support" has a significantly positive relationship with psychological detachment $(\beta$ $=.13, p<.01)$. Thus, family support would decrease the negative effects of technology use at home during off-job time on psychology detachment, thereby supporting $\mathrm{Hy}-$ pothesis 3. Model 5 shows that psychological detachment has a significant negative impact on time-based work-family conflict $(\beta=-.32, p<.001)$, and the interactive effect of "technology use for work at home during off-job time $\times$ family support" becomes insignificant (changed from $\beta=$ $-.11, p<.05$ to $\beta=-.06, n . s$.$) . Hence, Hypothesis 4 \mathrm{a}$ is supported, and family support negatively moderates the relationship between technology use at home during off-job time and time-based work-family conflict through the mediating effect of psychological detachment.

We can conclude from Model 7 that technology use for work at home during off-job time has positively significant effect on strain-based work-family conflict $(\beta=.14, p<$
.01), thereby supporting Hypothesis $1 \mathrm{~b}$. The interactive term "technology use for work at home during off-job time $\times$ family support" was included in Model 8 and the coefficient is significant $(\beta=-.13, p<.01)$. This result indicates that family support has a negative moderating influence on the main effect of technology use for work at home during offjob time on strain-based work-family conflict, thereby supporting Hypothesis 2b. Model 10 shows that psychological detachment has a significant negative effect on strain-based work-family conflict $(\beta=-.31, p<.001)$, and the interactive term "technology use for work at home during off-job time $\times$ family support" became insignificant (changed from $\beta=$ $-.13, p<.01$ to $\beta=-.09, p<.05$ ). Therefore, Hypothesis $4 \mathrm{~b}$ is supported, such that family support negatively moderates the relationship between technology use at home during off-job time and strain-based work-family conflict through the mediating effect of psychological detachment.

To demonstrate the moderating effect in a direct manner, we drew the graphs of $\mathrm{H} 2 \mathrm{a}$ and $\mathrm{H} 2 \mathrm{~b}$ according to Aiken and West (1991) as Figures 2 and 3, respectively). In figure 2 , it shows that for employees with low family support, technology use for work at home during off-job time has considerable positive effect on time-based work-family conflict compared with those who perceived high family support. Figure 3 shows that for employees with low family support, technology use for work at home during off-job time has considerable positive effect on strain-based workfamily conflict than employees with perceived low family support. 


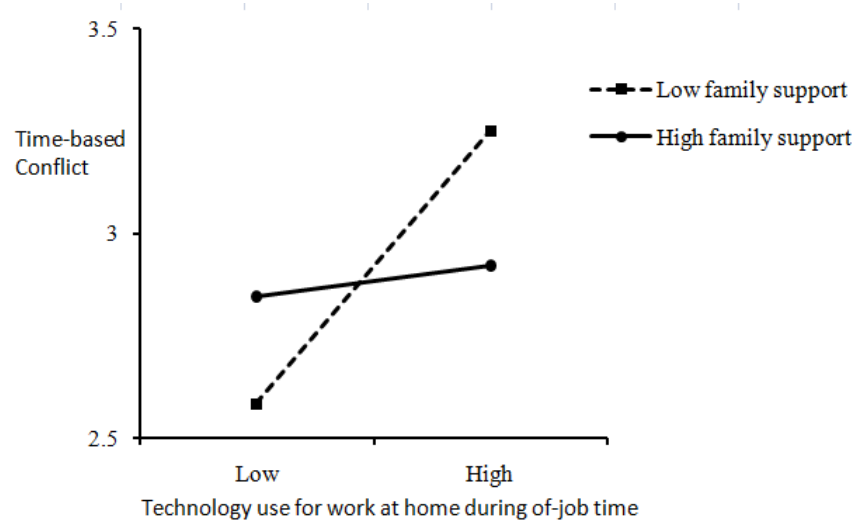

Figure 2. The moderation effect of family support on relationship between technology use for work at home and time-based work-family conflict.

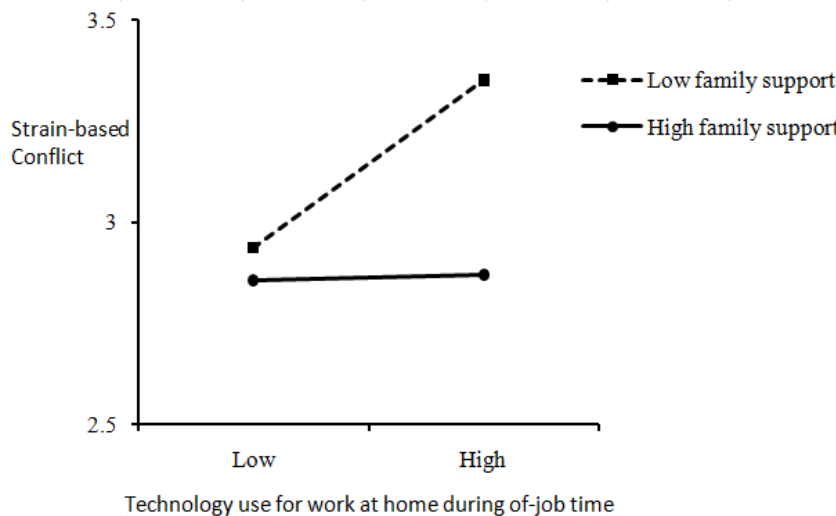

Figure 3. The moderation effect of family support on relationship between technology use for work at home and strain-based work-family conflict.

\section{Discussion and Conclusion}

We investigate how technology use for work at home during off-job time influences work-family conflict of employees and reveal the effect of psychological detachment (mediator) and family support (moderator). This study expands the application of work-family border theory and explains the phenomenon of how technology use for work at home during off-job time influences the work and family life of employees.

The empirical test reveals several interesting results. First, technology use for work at home during off-job time has significantly positive effect on both time-based and strain-based work-family conflicts. This finding is consistent with previous studies showing that high-level mobile technology use or information communication technology use positively correlated with high-level work-family conflict during nights, weekends, and vacations; employees can hardly devote time to family life because of problems at work or job worries (Chesley, 2005; Richardson \& Thompson, 2012). Boswell and Olson-Buchanan (2007) explained that using technology relevant to work during off-job time will intensi- fy employees' work-family conflict. Second, family support for employees will moderate the relationship between technology use for work at home during off-job time and workfamily conflict (time-based and strain-based). The influence of technology use for work at home during off-job time on work-family conflict (time-based and strain-based) will be weak for employees with higher family support than those with lower family support. Family support decreases the effects of technology use for work at home during off-job time on family border. This result is consistent with the implication of work-family border theory. Hence, understanding and support from border-keepers will ease the role conflict of border-crossers, as well as assist border-crossers achieve an improved balance between working and nonworking life. Third, psychological detachment plays a mediating role between the interactive term (technology use for work at home during off-job time $\times$ family support) and work-family conflict (time-based and strain-based). The effect of family support will enable an employee to feel less psychological detachment from work while at home, thereby further decreasing the level of work-family conflict.

Our study has several practical implications. On the one hand, family support will decrease the positive relationship between technology use for work at home during off-job time and work-family conflict (time- and strain-based). For example, managers can invite family members of employees to participate in company events for them to understand the nature, content, and importance of the employees' work. Thus, family members could provide psychological support to employees. This strategy contributes to psychological detachment from the working status while at home. On the other hand, employees who use technology to work at home during off-job time will have low psychological detachment, thereby making it difficult for them to be separated from work status. Such situation could further intensify the conflict. Given that employees work at home, the physical border of work and family life could become vague, thereby resulting in intensified conflict. Therefore, we suggest that while working at home, employees should clearly define their different roles in the two domains and take measures to minimize the overlap of roles. For example, employees could set working and nonworking schedules, establish a work zone or desk, and avoid dealing with work matters upon leaving the working zone. By differentiating time and space, employees may detach from work easily. Moreover, emotional management training program could be a good solution for companies to assist employees to control their emotions better. Hence, employees could recover from work status immediately and increase their psychological detachment.

This study also has several limitations that need to be addressed. First, we did not survey and distinguish the willingness/preference of employees to use technology for work during off-job time, which may influence work-family conflict as well. Moreover, the samples of our survey comprised employees who had fixed working schedule. The results may 
not be applied to employees who do not have fixed working schedule (i.e., managers or sales representatives). This study merely analyzed the moderating effects of family support; hence, we recommend conducting further research to advance the moderating effects of organizational support and other types of support, such as supervisor and coworker support. Finally, we distributed our questionnaires at two

\section{References}

Adkins, C. L, \& Premeaux, S. A. (2014). The use of communication technology to manage work-home boundaries. Journal of Behavioral \& Applied Management, 15(2), 82-100.

Aiken, L. S., \& West, S. G. (1991). Multiple Regression: Testing and Interpreting Interactions. Thousand Oaks, CA: Sage.

Allen, T. D., \& Finkelstein, L. M. (2014). Work-family conflict among members of full-time dual-earner couples: An examination of family life stage, gender, and age. Journal of Occupational Health Psychology, 19(13), 376-384. doi: 10.1037/a0036 941.

Bagger, J., \& Li, A. (2014). How does supervisory family support influence employees' attitudes and behaviors? A social exchange perspective. Journal of Management, 40(4), 1123-1150. doi: $10.1177 / 0149206311413922$.

Behson, S. J. (2002). Coping with family-to-work conflict: The role of informal work accommodations to family. Journal of Occupational Health Psychology, 7(4), 324- 341. doi:10.1037/1076-8998.7.4.324.

Boswell, W. R., \& Olson-Buchanan, J. B. (2007). The use of communication technologies after hours: The role of work attitudes and work-life conflict. Journal of Management, 33(4), 592-610. doi: 10.1177/0149206307302552.

Byron, D. (2005) . A meta-analytic review of work-family conflict and its antecedents. Journal of vocational behavior, 67(2), 169-198. doi:10.1016/j.jvb.2004.08.009.

Caren, B. F., Elizabeth, B., Dena, B. D., \& Joseph, S. (2002). Sources of social support and burnout, job satisfaction, and productivity. Journal of Occupational Health Psychology, 7(1), 84-93. doi:10.1037/1076-8998.7.1.84

Carlson, D. S. (1999). Personality and role variables as predictors of three forms of work-family conflict. Journal of Vocational Behavior, 5(2), 111126. doi:10.1006/ jv be.1999.1680.

Chesley, N. (2005). Blurring boundaries? Linking technology use, spillover, individual distress, and family satisfaction. Journal of Marriage and Family, 67(5), 1237-1248. doi: 10.1111/j.1741-3737.2005.00213.x.

Chesley, N., Moen, P., \& Shore, R. P. (2003). It's about time: Couples and careers. New York, NY: Cornell University Press.

Clark, S. C. (2000). Work/family border theory: A new theory of work/family balance. Human Relations, 53(6), 747-770. doi: 10.1177/0018726700536001.

Crzywacz, J. G., \& Marks, N. F. (2000). Reconceptualizing the work-family interface: An ecological perspective on the correlates of positive and negative spillover between work and family. Journal of Occupational Health Psychology, 5(1), 111-126. doi:10. 1037/1076-8998.5.1.111.

Edley, P. P. (2001). Technology, employed mothers, and corporate colonization of the life world: A gendered paradox of work and family balance. Women and Language, 24(2), 28-35.

Ellison, N. B. (2004). Telework and social change: How technology is reshaping the boundaries between home and work. Westport, CT: Praeger

Etzion, D., Eden, D., \& Lapidot, Y. (1998). Relief from job stressors and burnout: Reserve service as a respite. Journal of Applied Psychology, 83(4), 377-585. doi: 10. 1037/0021-9010.83.4.577.

Fritz, C., Yankelevich, M., Zarubin, A., \& Barger, P. (2010). Happy, healthy and productive? The role of detachment from work during non-work time. Journal of Applied Psychology, 95(5), 977-983. doi:10.1037/a0019462.

Golden, A. G. (2013). The structuration of information and communication technologies and work life interrelationships: Shared organizational and family rules and resources and implications for work in a hightechnology organization. Communication Monographs, 80(1),101-123. doi: 10.1080/03637751.2012.739702. time points with an interval of two months, thereby reducing common method bias. However, this measure may still be insufficient. Therefore, we recommend that scholars to conduct future studies by longitudinal design to confirm the casual relationship between psychological detachment and work-family conflict.

Greenhaus, J. H., Bedeian, A. G., \& Mossholders, K. W. (1987). Work experience, job performance, and feelings of personal and family well-being. Journal of Vocational Behavior, 31(2): 200-215. doi:10.1016/00018791(87)90057-1.

Greenhaus, J. H., \& Beutell, N. J. (1985). Sources of conflict between work and family roles. Academy of Management Review, 10(1), 76-88. doi: 10.5465/AMR.1985.427 7352.

Hall, D. T., \& Richter J. (1988). Balancing work life and home life: What can organizations do to help? Academy of Management Executive, 2(3), 213 223. doi: 10. 5465/AME.1988.4277258.

Hui, C., Lee, C., \& Rousseau, D. M. (2004). Psychological contract and organizational citizenship behavior in China: investigating generalizability and instrumentality. Journal of Applied Psychology, 89(2), 311-321. doi:10.1037/0021-9010.89.2.311.

Kelloway, E. K., Gottlieb, B. H., \& Barham, L. (1999). The source, nature, and direction of work and family conflict: A longitudinal investigation. Journal of Occupational Health Psychology, 4(4), 337-346. doi:10.1037/10768998.4.4.337.

König, A., Kammerlander, N., \& Enders, A. (2013). The family innovator's dilemma: How family influence affects the adoption of discontinuous technologies by incumbent firms. Academy of Management Review, 38(3): 428-441. doi: 10.5465/a mr.2011.0162.

Madsen, S. R. (2003). The effects of home-based teleworking on workfamily conflict. Human Resource Development Quarterly, 14(1): 35-58. doi: 10.1002/hrdq.1049

Muller, D., Judd, C. M., \& Yzerbyt, V. Y. (2005). When moderation is meditated and mediation is moderated. Journal of Personality and Social Psychology, 89(6), 852- 863. doi:10.1037/0022-3514.89.6.852.

Parasurman, S., \& Simmers, C. A. (2001). Type of employment, work-family conflict and well-being: A comparative study. Journal of Organizational Behavior, 22(5), 551- 568. doi: 10.1002/job. 102.

Park, Y., Fritz, C., \& Jex, S. M. (2011). Relationships between work-home segmentation and psychological detachment from work: The role of communication technology use at home. Journal of Occupational Health Psychology, 16(4), 457-467. doi:10.10 37/ a0023594.

Pleck, J. H. (1977). The work-family role system. Social Problem, 24(4), $417-$ 427. doi: $10.2307 / 800135$.

Pleck, J., Staines, G., \& Lang, L. (1980). Conflicts between work and family life. Monthl Labor Review, 103(3), 29-32.

Podsakoff, P. M., MacKenzie, S. B., Lee, J. Y., \& Podsakoff, N. P. (2003). Common method biases in behavioral research: A critical review of the literature and recommended remedies. Journal of Applied Psychology, 88(5), 879-903. doi: 10.1037/0021-9010.88.5.879.

Powell, G. N, \& Greenhaus J. H. (2010). Sex, gender, and the work-family interface: exploring negative and positive interdependencies. Academy of Management Journal, 53(3), 513-534. doi: 10.5465/AMJ.2010.51468647.

Richardson, K. M., \& Thompson, C. A. (2012). High tech tethers and workfamily conflict: A conservation of resources approach. Engineering Management Research, 1(1), 29-43. doi: 10.5539/emr.v1n1p29.

Richter, J. (1992). Balancing work and family in Israel. In S. Zedeck (Ed), work, family and organizations (pp. 362-394). San Francisco, CA: Jossey-Bass.

Shamir, B. (1992). Home: The perfect workplace? In S. Zedeck (Ed), work, family and organizations (pp. 272-311). San Francisco, CA: Jossey-Bass.

Sonnentag, S., \& Bayer, U. (2005). Switching off mentally: Predictors and consequences of psychological detachment from work during off-job time. Journal of Occupational Health Psychology, 10(4), 393-414. doi: 10.1037/1076-8998.10.4.393. 
Sonnentag, S., Binnewies, C., \& Mojza, E. J. (2008). Did you have a nice evening? A day-level study on recovery experiences, sleep, and affect. Journal of Applied Psychology, 93(3), 674-684. doi: 10.1037/00219010.93.3.674.

Sonnentag, S., \& Fritz C. (2007). The recovery experience questionnaire: Development and validation of measure for assessing recuperation and unwinding from work. Journal of Occupational Health Psychology, 12(3), 204-221. doi: 10.1037/10 76-8998.12.3.204

Sonnentag, S., Kuttler, I., \& Fritz, C. (2010). Job stressors, emotional exhaustion, and need for recovery: A multisource study on the benefits of psychological detachment. Journal of Vocational Behavior, 76(3), 355-365. doi:10.1016/j.jvb.2009.06.005.
Teo, S. T., Newton, C., \& Soewanto, K. (2013). Context-specific stressors, work-related social support and work-family conflict: A mediation study. New Zealand Journal of Employment Relations, 38(1), 14-26.

Treiber, L. A., \& Davis, S. N. (2012). The role of 'workplace family' support on worker health, exhaustion and pain. Community, Work \& Family, 15(1), 1-27. doi: 10.1080/ 13668803.2011.580123.

Williams, K., \& Alliger, G. M. (1994). Role stressors, mood spillover, and perceptions of work-family conflict in employed parents. Academy of Management Journal, 37(4), 837-868. doi: 10.2307/256602.

(Article received: 02-10-2015; revised: 21-04-2016; accepted: 22-05-2016) 